であるが，a）については松井浩氏，b）については河口 広司氏 c）については吉野耕一氏 d) 扎よび文献目録 については高橋務氏にとれぞれまとめを㹉願いした。図
版その他については高橋正雄氏に御助力を載いた。

この紹介が多少とも会員諸氏洋益するとろがあるこ とをを期待する。

\title{
I. 放電の電気的特性一放電路の電気伝導度
}

\author{
松井浩*
}

\section{Part I. Electric Conductivity of Discharge Channel}

\author{
Hiroshi MATSUI
}

Kawasaki Branch of Industrial Research Institute of Kanagawa Prefecture (157, Minamisaiwai-cho-3, Kawasaki City, Kanagawa Prefecture, Japan)

\section{1. 定性的な像}

現在パルス放電の電気的特性を決定するのに二つのア プローチがある、第一は主としてギャップを含芑回路の 電気的な量, すなわらインピーダンスの時間的変化を数 学的纪解析することである. 第一はギャップのコンダク タンスを決定する過程を直接物理的に調べることであ る.とのレビューでは物理に重点を置いて第二のアプロ 一チを詳細に考光て見よう。

絶縁破壞が進行している間，電流密度が増大するのは 次から次えと連続してますます速度を増して起こる一連 のなだれ的な過程によるものである; これらの過程は電 子による衝突電離 ( $\alpha$ 電離), $\alpha$ 電離之 $\Gamma$ 電離 (陰極面 上の二次過程）との間の相互作用，平面状空間電荷の $\alpha$ 電離と $\Gamma$ 電離に和よぼす放果， $\alpha$ 電離とガスそれ自体 の光電離とストリーマベッドに集中した空間電荷との間 の相互作用等々である. ヘッドのあとにできた放電路の 長さ方向の電場はギャップ間の電位差（へッドとそれと 向きあっている電極との間の電圧降下を差し引いたもの で, これらの電厓降下は放電路がギャップの全長に成長 した後は電極降下になる) と放電路の長さとの比に等し い. もし放電々源の容量が充分大きく（放電回路の抵抗 とインダクタンスが小さくコンデンサの容量が大きい） ギャップ電圧が電極降下の和の何倍も高い場合に最も強 いなだれが起こるだろう．放電路中の気体が相当程度励 起し電離しているためと多数の粒子が相互に大きい影響 を叔よ゙し合っているため, 原子, イオン, 電子, 光子間

* 神奈川県工業試験所川崎支所(川崎市南幸町3の157)
のいろいろな基本的な相互作用はこの段階ではもはや別 々に考えることができない.ここでは結果的な熱電離か あるい注不完全な熱平衡の場合には熱電離のある種の類 似について一般的に述べることだけが意味のあることに なるだろう，長さ方向の電場によってできたこのなだれ は放電路で消費されるエネルギーと放電によって発生す る電力の影響を受けて増大する気体の熱電離からなる。 ついでこの電力は電離が増すため電流密度が増加しその 結果さらに增大する。

このなだれ過程は電流密度 $j$ (これ机電場をかけると 単位体積当りに費される電力になる), 熱電離 $X$, 電場 の強さ $E$ に対する数式を考えれば明確になる.

$$
\begin{aligned}
& j=\frac{0.75 n e_{0}^{2}}{\sqrt{\frac{8}{\pi} k T m}} \times \lambda E \\
& \frac{X}{\sqrt{1-X}}=\frac{0.9}{\sqrt{p_{0}}} T^{\frac{3}{4}} e^{-5850 \frac{V_{i}}{T}} \\
& E l=U_{0}-U_{e}-L \frac{d I}{d t}-R_{b} I-\frac{1}{c} \int_{0}^{t} I d t
\end{aligned}
$$

ここに $n-\mathrm{cm}^{3}$ 当りの原子数 (中性あるいはイオン), $e_{0}$ と $m$-電子の電荷と質量, $k$-ボルッマンの常数, $T$ 一平均気体温度, これは電子温度に等しいと仮定する), $\lambda$ 一電子の平均自由行程, $p_{0}$-初期ガス圧, $V_{i}$-電離電 圧, $l$-電極間距離, $U_{e}$-電極附近の電圧降下の和, $I-$ 放電从流, $L$ と $R_{b}$-放電回路の外部インダクタンスと 抵抗, $t$ 一時間である.

（2）式は電離度が温度とともにいかに急激に増大する かということを現わしている（余り高くない温度で，こ 
の時には $5850 V_{i} \ll 1$, そして $\left.X \ll 1\right)$. (1) 式からもし $E$ が一定で $\lambda$ が $X$ に無関係ならば（(3) 式の右辺の $U_{0}$ 以 外の項が小さくそして総イオン断面が総原子断面よりず つと小さくなる位 $X$ が小さい時に)温度を決定する電力 は電離度に比例して増加することがわかる。このような 自己励起的またはなだれ的過程では, 電流密度は幾桁も 増大するが，次の原因（あるいはこれらの原因の組多合 わせ)によってのみこの増加は停止あるいは減速される。

1) より一層 $X$ が増加すると $E$ が低下して $j$ の増加 が不可能になるから放電で消費される電力の増加が止ま る. この $E$ の低下は (1 a) 外部放電回路の特性 $(R, L$, 小さい C) によるものかあるいは（1 b) $j$ の大きい場合 に注電極降下 $U_{e}$ の増加によるものである.

2）電子は本来原子によってではなくイオンによって 散乱されるものである. 離度と総イオン断面の増加によって電流密度の増大が阻 止される.

3）放電で消費される電力が放射パワー（温度ととも に急激に増加する）と等しくなって未るため温度の上昇 が止まる。

熱平衡が成立する前の熱電離や放電路から周囲へ逃げ るエネルギーの損失を計算できないから，この過程を純 理論的な方法では完全に説明できないが，電気的特性の 時間変化に関する実験データ（ギャップ電圧や放電々 流, 電力や電流の時間微分のようなこれらの量のいろえ な関数等）でもってこの過程の前述の説明を補足でき る.とれ以上の情報を得るためには

a) なだれ過程の非定常相の間の $I$ と $d I / d t$ の増加特 性とUの低下特性およびそれらの持続時間を測定しな ければならない。

b）このなだれ過程が終了する実際の原因と終了後の 放電特性を確かめ秝ばならない。

一般的にいえば電気的特性のオシログラムを得るのは 非常に困難であるし，たとえ前述のフォクターのどれか が電流密度の增加を止め放電を準定常状態にさせたとし ても, 放電路が膨脹するため電流は急激な増加を続ける ので後者の問題に答えることは寺ずかしい.たとえば大 気王の空気の絶縁破壞では, 初期の放電路の直径はス卜 リーマの直径（０.1 mm） 飞等しい. もし準定常放電 になる前の約 $50 \times 10^{-9}$ 秒間 $j$ が増加し続け, それから 放電路が衝撃波速度 $\left(\sim 10^{-5} \mathrm{~cm} / \mathrm{sec}\right)$ で膨脹するつまり 放電路の直径 $d$ が $2 \times 10^{5} \mathrm{~cm} / \mathrm{sec}$ の速さで増加する ならば， $j$ の増加が止まった後の $50 \times 10^{-9}$ 秒間に $d$ は $0.1 \mathrm{~mm}$ だけ増加する, すなわち電流は $j$ が一定であっ ても $j$ がなだれ的に増加している間と同じオーダーで増
加する. 最初の $d$ の絶体值が小さければ,この増加率は もっと速くなり得る.

したがって電気的特性のオシログラムをとることによ ってこの問題它解くためには, 放電路を人為的に閉ぢ込 めた実験を行なえば多くの情報が得られるということに なる.

もし放電回路の抵抗がかなり大きければ, 電流がな だれ的に増加すると（3）式に従ってギャップ電圧 $U\left(=E l+U_{e}\right)$ 法 $U_{0}$ の值と安定抵抗 $R_{b}$ とで決まるア 一クのギャップ電圧に急激に低下する.この種の電圧変 化は Fig. 1 の curve 1 で示されている. 有効抵抗 $R_{b}$ が無視できるほど小さく䉓源コンデンサ C の容量が充 分大きい場合には，電流の急激な増加による $U$ の低下 ほ $L d I / d t$ に泳ならない. もし $L$ が充分小さく $d I / d t$

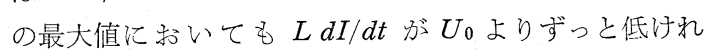
ば, $U$ の変化は強電流段階の初期で Fig. 1 の curve 2 および 3 の $\mathrm{ABC}$ 部の形になるはずである. 放電路が束 縛されていない時には, その後のUの変化は放電路が 膨脹した結果, 電流強度の増加が遅らされた定容量のコ ンデンサ放電のような CE 部になるだろういうことが予 想される. 他方も乙放電路の直径が人為的にある值に制 限されている場合, 放電路が膨脹してその直径に到達す る時刻 $C$ までには $j$ 占最大值に達しているならば，その 時の電流もまた最大になるはずである. この場合 $d I / d t$ は消え $U$ は D 点へ上昇する（放電路の膨脹の遅机は漸 進的で $U$ が高くなると $j$ をまた増加させることになる から，この過程は瞬間的なものではない). コンデンサ 放電がさらに進むにつれて $U$ は $D E_{1}$ に従う。

このようにもし放電路が束縛されていない時の電圧才 シログラムが $A B C E$ の形になれば， $j$ の増加が止まる のは電源の内部インピーダンスのため（原因 $1 \mathrm{a}$ ）ばか りでなくすでに述べた他の三つの原因による可能性があ る. 一方放電路のある部分の直径を制限した場合のオシ ログラムが $A B C D E_{1}$ の形になれば，これはまさにその 部分の $j$ が限られた值をもつという証拠になる. もし電 極附近の放電領域でこの直径を制限した時（電極の表面 を小さい部分を残して絶縁物で覆ってしまう), このよ うな電圧変化が観測されれば，そこの $j$ には限度がある ことそして $j$ の值をもっと大きくするには，それに相応 する電極附近の電圧降下 $U_{e}$ を増加する必要がある（原 因 1 b) ことがわかる。も乙電極の動作面積が何ら影響を およぼさないととがわかりそして放電コラムが管壁によ って閉じ込められた時のオシログラムが $A B C D E_{1}$ の形 になれば，原因 2 と 3 方主要な役割を演じていることに なる．との時の電流オシログラムから最大電流密度の絶 


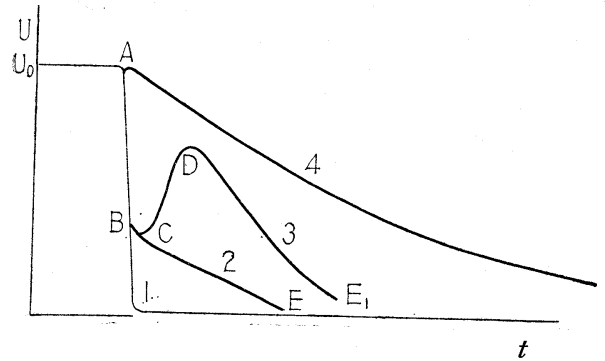

Fig. 1-1. Expected variation of voltage in a pulse discharge, fed from a discharge circuit with large active resistance (1), with sufficiently small resistance and inductance and large capacitance (2case of unbounded channel, 3-channel of limited diameter), and also in a discharge with artificially increased distance between electrodes (4).

体測定が可能になりとしてそれによってこの二つの原因 のおのおのの役割がもっと明確になる。

チューブラフラッシュランプのように補助電圧電源で ギャップをあらかじめ電離させておくことによって放電 路の長さを人為的に長くするか, あるいはあらかじめ電 流によって長い金属線を爆発させ，その蒸気中にパルス 放電をとばすと初期の放電路の長さ方向の電場をかなり 弱めることができる. 原因 2 または 3 が効果的な場合に は, 最大電流密度および最大電流強度は短いスパークギ ヤップの時よりずっと小さくなるにらがいない.したが って curve 3 の $A B C D$ 部は $L$ が小さい場合には, も っとずっと小さいスパイクになる (curve 4). この辛う じて認め得るスパイクの後の $U$ はゆっくりと抵抗值が 変って行く抵抗を通してキャパシタが放電する時のよう に変化する.

\section{2. 実験資料 Experimental Material}

\section{1 電流密度のなだれ的な増加}

(Avalanche-like buildup of current density) 放電回路の抵抗 $R_{b}$ が大きい（数千オーム）場合ギャ ップ電圧 $U$ は絶縁破壊の開始直後の数十ナノ秒（ナ， 秒は $10^{-9}$ 秒) 以内に数千ボルトの $U_{0}$ からほぼアーク のギャップ電圧に等しい数ボルトに collapse (低下)す ることはずっと以前に立証されている. この collapse は多くの研究者達によって調べられて来たが， $U_{0} の$ 60 ～ $80 \%$ のレベルで起こり数百ナノ秒で終る急激な電 圧の低下に一時的な中断—これは電圧棚（voltage ledge）と呼ばれる—があることが報告されている. この棚は短時間の拡散グロー放電相（short-duration diffuse glow discharge phase)一高度にイオン化した プラズマが収縮してチャネル(放電路)を形成する前の段 階—と結びつけられている. この棚は $R_{b}$ が大きい場 合に観察されたものでその相の放電々流は 1 アンペア程 度の小さいものである. $L$ と $R_{b}$ 沜小さい時は, たいて いの場合この棚は見られない.しかし $R_{b}$ が無視できる ほど小さく $L$ が $3.6 \mu \mathrm{H}$ の場合でさえこの棚が見られ, その際の放電々流は棚の終りに注 10〜100アンペアにも 達したという報告もある. 過電圧を数パーセント高くす ると棚の持続時間は短くなり，乙まいには完全になくな る,すなわち拡散放電の電流が約 $10^{-2}$ アンペアを越え る前の相で熱電離が急速に進展すると共に収縮した放電 路ができる.この棚と電源回路の電力との依存関係およ びずっと小さい $L$ の場合に生ずるかどうかという閴題 は今な抹末解決のままである。

Collapse の最も急激な部分の時間 $t \mathrm{col}$ ほ通常の放電 回路では 10-8 秒のオーダーである.1例をあげれば大 気圧の空気では 30 ナノ秒, $250 \mathrm{mmHg}$ の時には 100 ナ ノ秒で水素の場合は空気の $1 / 3$ である. collage 前の電 圧がわずか低いのは水素の著しい特徵であるが，これは 水素中の絶縁破壊の初期の電場が空気の時より弱いこ と, したがって熱電離の開始に必要なエネルギーの放出 がより緩慢なことに結びつけられる. Fig. 2 注電流と 電圧のオシログラムを同時にとることによって得られた 放電で消費される電力の曲線を表わす．これらの曲線か ら水素では空気の二倍の圧力で同量の電力が得られるこ とが確かめられる。

放電回路の $L$ を小くすると $t \operatorname{col}$ は短くなる.たと えば $L \sim 10 \mathrm{nH}$ の時には 6〜8ナノ秒である. 高い過電 圧を用いるとさらに短くなる。短いギャップ $l=0.03$ $0.11 \mathrm{~mm}$ ，非常に小さい $C=130 \mathrm{pF}$ と $L \sim 0.6 \mathrm{nH}$ の 回路で立ち上りの勾配が $0.75 \sim 2.5 \mathrm{kV} / \mathrm{n} \mathrm{sec}$, 波高值が $300 \%$ の過電圧の衝撃電圧を用いた実験では, 熱電離し たプラズマの形成時間は 0.2 ナ秒になり,これでもま だ限界ではないらしい.

このように電流密度が増大する時間とそれに伴うギャ ップ電压の collapse をギャップと放電回路のパラメー タの関数として表わした完全な像はまだない、けれども 今までの実験資料は静的な（衝撃電圧を用いない）絶縁 破壊の場合，電離度が数パーセントに達するのに要する 時間を求ぬる試夕の計算の結果 $\left(\sim 10^{-9}\right.$ 秒 $)$ と良く一致

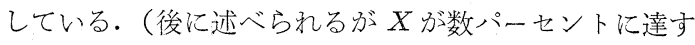
ると電流密度のなだれ的な增大が止る.）高い過電圧を 


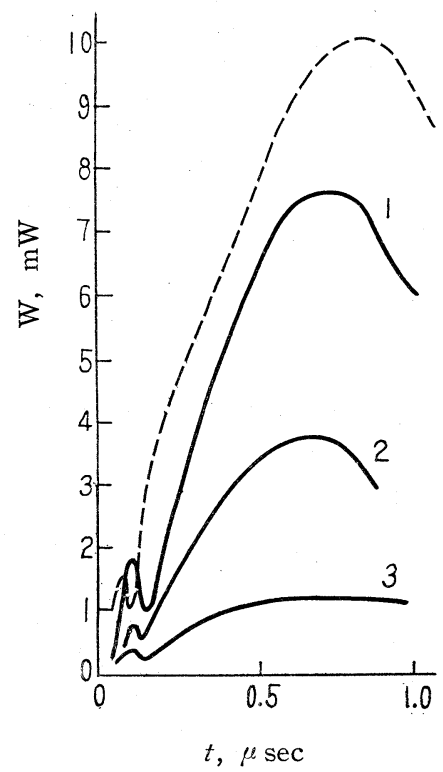

Fig. 1-2. Power dissipated in the discharge for breakdown in air (dashed curve, pressure $p=750 \mathrm{mmHg}, \quad U=35.3 \mathrm{kV})$ and hydrogen (solid lines). $\quad 1-p=1500 \mathrm{mmHg}, \quad U_{0}=$ $32.5 \mathrm{kV} ; \quad 2-p=1000 \mathrm{mmHg}, \quad U_{0}=25 \mathrm{kV}$; $3-p=500 \mathrm{mmHg}, \quad U_{0}=13.5 \mathrm{kV}, \quad C=0.06$ $\mu \mathrm{F}, L=3.6 \mu \mathrm{F}$. Distance between electrodes $l=11.7 \mathrm{~mm}$.

用いギャップ一放電回路の $L$ が小さい場合にはこの時 間は当然もつと短くなるはずである。

\section{2 電流密度のなだれ的な増加の停止}

(Cessation of avalancke-like growth of current density)

放電回路の抵抗 $R_{b}$ が大きい時, collapse が終了した 瞬間に電流密度のなだれ的な増加が止るのは主として原 因 $1 \mathrm{a}$ 一外部放電回路のインピーダンスのため長さ方 向の電場が弱くなる——よるものである。この瞬間に は電流密度 $\left(\sim 10^{4} \mathrm{~A} / \mathrm{cm}^{2}\right)$ とガス密度が大きいという 特徵があるが，この放電は原理的には通常のアークと異 なつていない，そののち放電路は太くなつて電流密度は 通常のアークのそれと一致する．放電路が膨脹するのに 従つてその抵抗值は小さくなるが, collapse 直後すでに $R_{b}$ よりずつと小さくなつているから電流強度にはほと んど影響しない。この全過程は Fig. 1 の curve 1 で 説明されている機構に相当する， $R_{b}$ が小さくて $L$ が大 きい場合にも同様の形になる. 電流密度がなだれ的に増 加している間にギャップ電圧は 200 300 V に collapse し，その後の変化は電流変化と同様 $L C$ 回路から給電さ
れた強電流アークの変化と急速に一致する. collapse が 終わる瞬間と通常のアークになる瞬間との間に短い遷移 期間（この間に放電路が太くなる）があるけれども，電 流密度の增加を停止させるのは疑いもなく原因 $1 \mathrm{a}$ で ある。

$R_{b}$ と $L$ が小さくて $C$ が大きい場合には全く異なつ た過程が起こる. Fig. 3 は空気の絶縁破壞の際の電圧, 電流, 電流の時間徵分の典型的なオシログラムである が, 電圧変化は Fig. 1 の curve 2 と良く一致してい る. collapse の間に電流密度は限られた值に達するが, 引き続き放電路が膨脹するため電流強度はほとんど一定 の $d I / d t$ で増加し続ける. $d I / d t$ の最大值を過ぎた後 の $U$ の低下は明らかにコンデンサの放電によるもので ある(この時刻にはすでに $\frac{1}{C} \int_{0}^{t} I d t と L d I / d t$ が同程 度になる). collapse し終つた瞬間のギャップにはかな りの電圧 $U_{i}$ が残つているが，この $U_{i}$ は $L$ を減らす か， $U_{0}$ と $l$ を大きくすれば高くなる. 放電領域の各部 を制限することによつて電流密度には限度のあることの 理由を見出すための実験がなされた。陰極または陽極の 表面它絶縁物で覆い約 $0.05 \mathrm{~mm}^{2}$ だけ露出しておいた

$\mathrm{U}, \mathrm{kV}$

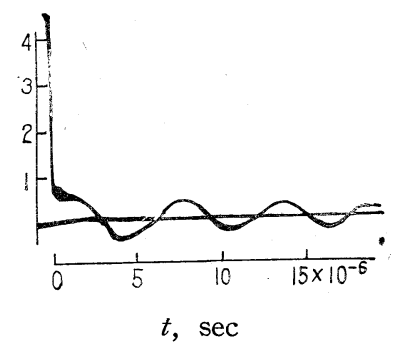

I, A
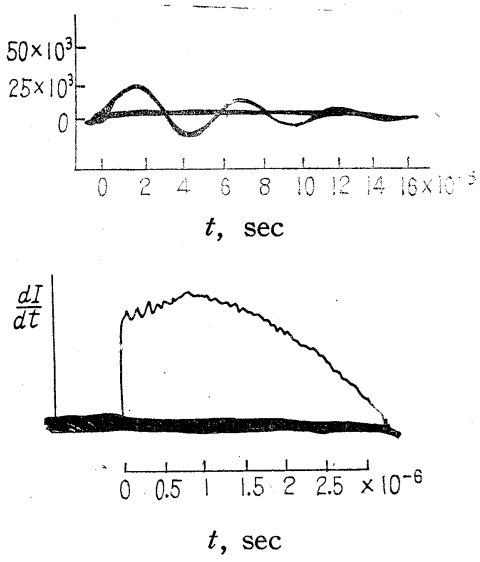

Fig. 1-3. Typical oscillograms of $U, I$, and $d I / d t$ for a discharge with unbounded channel. Air, $p=760 \mathrm{mmHg} ; l=1.5 \mathrm{~mm}$, $C=6 \mu \mathrm{F}, U_{0}=4.5 \mathrm{kV}, L=0.16 \mu \mathrm{H}$. 
場合でも，オシログラムの波形に変化が認められなかつ た.このことから電極附近の電流密度には限度がないこ と（㓌極点および陽極点の電流密度を測定した実験によ ると, $4 \times 10^{7} \mathrm{~A} / \mathrm{cm}^{2}$ のオーダーの值が得られている)と collapse 後の高い電位差は電極附近の電位降下に集中 （原因 1 b) 乙ていないことがわかる.これと反対にキャ ピラリの管壁で放電路を閉ら゙込めると Fig. 4 のような 全く異なつた形のオシログラムが得られる. これはFig. 1 の curve 3 と良く一致しているように, collapse の 後に電流密度は最大值に達しそして放電路が膨脹してキ ヤピラリの内側断面を満した後電流強度も最大值に達す るという放電に属する. 同様な形が $I$ と $d I / d t$ の才シ ログラムにもみられる. キャピラリの直径を小さくする と Fig. 1 の鞍部 $B C$ はより狭くなり瘤（こぶ） $D$ は もつと高くなる.

このように放電路中の現象によつて決まる（多分原因 2 または 3 によるものと思われる）ある限られた飽和電

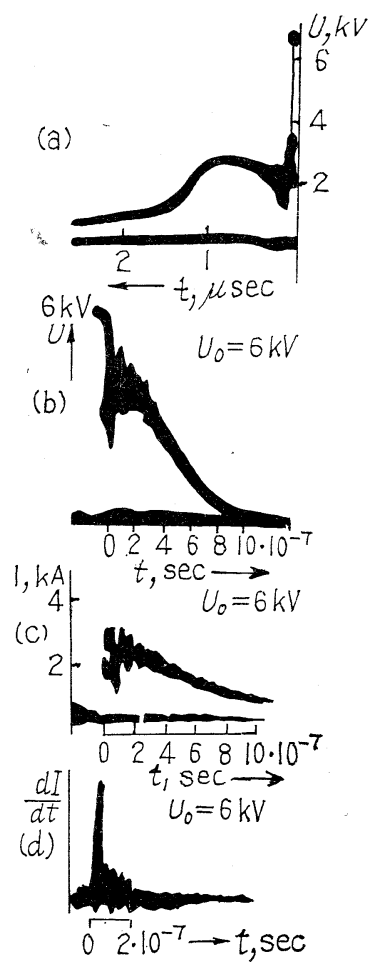

Fig. 1-4. Typical oscillograms of $U, I$, and $d I / d t$ for a discharge in a capillary (air, $760 \mathrm{mmHg}$ ). a) $C=\mu \mathrm{F}, U_{0}=$ $6.8 \mathrm{kV}, L=0.16 \mu \mathrm{H}$, capillary diameter $d=0.6 \mathrm{~mm}, l=3 \mathrm{~mm}$; b-c) $C=0.25 \mu \mathrm{F}$, $U_{0}=6 \mathrm{kV}, \quad L=0.08 \mu \mathrm{H}, \quad d=0.2 \mathrm{~mm}$, $l=5 \mathrm{~mm}$.
流密度 $j$ sat が存在することが穾験によつて確かめられ。 た. 電流および電圧オシログラムと放電路の直径に関す る実験データ（キャピラリの内径あるい滈速度撮影に よつて測定された放電路の直径）から得た $j$ sat とそれ に対しする $E$ の值（電極附近の電圧降下は考慮しない で), プラズマの比抵抗 $\rho=E / j$ の值を Table 1 にまと めておいてある.

Table 1 から次の事がわかる；1）束縛されない放電 路に対して各研究者達の出した $\mathrm{j}$ sat と $\rho$ の值は皆オー ダーが同じである. 数倍異なつているのは放電路の直径 を測定する方法が異なるためである。 $\rho$ の值は平均して キャピラリ中の放電（束縛された放電路）にくらべて幾: 分低目であるが，才一ダーは一致している；2）E㔔大 きいと $\rho$ が小さくなり $\mathrm{j}$ sat は大きくなる；3）ガスの 種類は $\rho$ と $j$ sat の值にほとえぞ影響しない.

チューブラフラッシュランプの場合に注補助高圧パル スによつてできた最初の細い放電路が膨脹して数マイク 口秒後には放電管内に大体均一に充満する.も乙電源二 ンデンサの容量が十分大きければ，放電路が膨脹する時 間は主放電の持続時間にくらべて無視できるほど短い. そしてこの主放電が持続する間は放電路の特性の変化は 全くゆつくりとしたもので，この放電を準定常放電と見 なすこと分できる。

上に考察したように空気中の短いスパーク放電とキャ ピラリ中の放電は類似しているが，チューブラフラッシ ニランプの放電には次の本質的な際立つた特幑がある:

1）不活性ガス中の放電であるから Ramsauer 効果 が顕著である，すなわ約 $10000^{\circ} \mathrm{K}$ の温度に相当する速 さをもつ電子を散乱する原子の衝突断面が小さい.した がつてこのような放電では比較的低い電離度 $\left(X=10^{-4}\right)$ でさえイオンの総衝突断面は原子のそれより大きくなり 始める.さらに $X$ が大きくなると，原子ではなくイオ ンによる電子の散乱の方が主役を演ずるようになり，電 流密度は $X \sim 10^{-4}$ で電離度に直接依存しなくなる（原 因 2).

2）補助高圧パルスを点火に用いているため，放電路 の長さは $U_{0}$ が同一の分子気体中のスパーク放電に比較 して一桁ないし二桁上である. 放電初期の $E$ は搦くな. るので最大電流密度および強度は低くなることが予想さ れる。

3）放電路の単位長当りで費される電力は小さいの で，相当長時間パワーを加えても管壁を損傷しない：こ のことは $C$ を大きくすることを可能し，したがつて準 定常放電の持続時間をキャピラリ中の短いスパーク放電 より数桁大きくすることができ，この放電の詳細な研究 
Table 1-1. Summary of experimental electric characteristics of powerful discharge after "collapse" of the voltage

\begin{tabular}{l|c|c|c|c|c|c|c|c|c}
\hline \hline Author & Reference & Gas & $\begin{array}{c}\text { Pres- } \\
\text { sure, } \\
\text { atm }\end{array}$ & $\begin{array}{c}\text { Dis- } \\
\text { charge } \\
\text { length, } \\
\text { mm }\end{array}$ & $\begin{array}{c}\text { Capillary } \\
\text { diameter, } \\
\text { mm }\end{array}$ & $L, \mu \mathrm{H}$ & $\begin{array}{c}j \text { sat, } \\
10^{5} \mathrm{~A} / \mathrm{cm}^{2}\end{array}$ & $E, \quad \mathrm{~V} / \mathrm{cm}$ & $\rho, 10^{-3}$ \\
$\Omega-\mathrm{cm}$
\end{tabular}

* Artificial line made of four $100 \mu \mathrm{F}$ capacitors spaced by $1.5 \mu \mathrm{H}$ inductances.

** Data on the dependence of the gap voltage on the length were used to estimate the near-electrode drops, which were taken into account in the calculation of $E$.

Table 1-2. First (essentially time-averaged) data by certain authors on the resistance of tubular flash lamps, recalculated for $\rho$ by means of formula (4)

\begin{tabular}{|c|c|c|c|c|c|c|c|}
\hline Author & Reference & Gas & $\begin{array}{c}\text { Pressure, } \\
\mathrm{mmHg}\end{array}$ & $r, \mathrm{~mm}$ & $l, \mathrm{~mm}$ & $\begin{array}{c}E, \\
\mathrm{~V} / \mathrm{cm}\end{array}$ & $\begin{array}{r}Q 10^{2}, \\
\Omega-\mathrm{cm}\end{array}$ \\
\hline 1. Laporte & 87 & Neon & 5 & 3 & 100 & 200 & 0.9 \\
\hline 2. Laporte & 87 & Argon & 5 & 3 & 100 & 200 & 1.3 \\
\hline 3. Murphy and Edgerton & $\begin{array}{c}34.35 \\
140\end{array}$ & $\begin{array}{c}\text { Argon, } \\
\text { xenon }\end{array}$ & $50-300$ & $3.5-7$ & $100-300$ & 175 & $1.1-3$ \\
\hline 4. Vul'fson & 215 & $\begin{array}{l}\text { Neon, } \\
\text { argon, } \\
\text { krypton }\end{array}$ & $5-10$ & $0.8-5$ & $50-500$ & 30,130 & 3 \\
\hline 5. Carlson and Pritchard & 19 & Xenon & 100 & 2.2 & 400 & 50 & 3 \\
\hline 6. Warmoltz and Helmea & $205^{b}$ & "1 & 200 & 2 & 200 & 200 & 1.6 \\
\hline $\begin{array}{l}\text { 7. Aldington and } \\
\text { Meadowcroft }\end{array}$ & 4,5 & "1 & 60 & 5.5 & 460 & 44 & 1.5 \\
\hline 8. Meyer & 133 & Argon & 200 & 5 & 800 & 100 & 1. $7-4.2$ \\
\hline 9. Glaser and Sautter & 67 & Xenon & 190 & 2 & 300 & 100 & 4.5 \\
\hline 10. Chesterman and Glegg & 20 & "I & 200 & 1.5 & 128 & 80 & 1 \\
\hline 11. Ando and Matsuoka & 6 & "l & $50-300$ & 2.5 & 150 & 17 & 2.6 \\
\hline 12. leCompte and Edgerton & 91 & "1 & 300 & 2 & 76 & 118 & 1.14 \\
\hline
\end{tabular}

* This column limits, for most investigations, the initial values of the gradient without account of the drops near the electrodes. Only for the investigations of Chesterman and Glegg and of leCompte and Edgerton, in which low capacitances only slighly discharged by the instant when the discharge tube was filled with plasma were used, is the instantaneous value of $E$ given for the maximum current strength. 
がずつと容易になる・

チニーブラフラッシランプの電気的特性に関する実験 データを Table 2 に示す. その放電回路の $R_{b}(0.01 \Omega)$ と $L(1 \mu \mathrm{H})$ 泟通常小さい. その電圧変化は Fig. 1 の curve 4 のようになり, 次第に $\exp (-t / R C)$ に近ゔ く. $R$ は次式から計算した放電路の抵抗である.

$$
R=\frac{\rho l}{\pi r^{2}}
$$

( $r$ 一管の内半径) $\rho$ は異なつた放電管や電源条件でも大 体同じ值になるが，Table 1 の值より 1 桁大きい. オシ ログラムに顕著な collaspe が現われないのは, $d I / d t$, $R_{b}, L$ の各值を見積つて見れば理解できる, すなわち初 期の放電路の径を $0.1 \mathrm{~mm}$ として, $j$ が最初の 107 秒 間に 0 からなだれ的に増加して $23 \times 10^{3} \mathrm{~A} / \mathrm{cm}^{2}$ になつ たのだから $d I / d t \sim 10^{7} \mathrm{~A} / \mathrm{sec} ; j$ の増加が止り, 放電路 の半径が $500 \mathrm{~m} / \mathrm{sec}$ の速さで膨脹し, 直径が $1 \mathrm{~mm}$ にな つたときの $d I / d t \sim 5 \times 10^{7} \mathrm{~A} / \mathrm{sec} ;$ したがつて $L d I / d t$ や $R_{b} I$ は $10 \mathrm{~V}$ のオーダーになるが，乙机は普通用い られる $U_{0}$ にくらべて無視できるほど小さい. しかし $L$ を大きくすれば Fig. 1 の curve 3 に，Rを大きくすれ ば curve 1 にそれぞれ似てくる. (その時には $L d I / d t$ そ $R_{b} I$ は $U_{0}$ と同程度になるからである.)

電流によつて爆発させた金属線の蒸気中の放電につい ても, 同様な実験データが得られている.たとえば銅線 が爆発してから約 2 マイク口秒の後, 放電は成長しつつ ある細い線の形で始まる. その時にはすでに稀薄になつ た銅の蒸気はあたか子管壁のような衝撃波の波面で囲ま れた直径約 $6 \mathrm{~mm}$ の円筒内に充満する. 約 3 マイクロ秒 後には放電路は, 直径 $8 \mathrm{~mm}$ になつたこの円筒内に拡が る. 実験データによると, このプラズマの $\rho$ は金属の種 類や線の直径とは無関係に $E \sim 250 \mathrm{~V} / \mathrm{cm}$ において約 $0.008 \Omega-\mathrm{cm}$ で, これは不活性ガスを充塡した放電管と 同じオーダーである.

\section{$2.3 \rho$ の $\boldsymbol{E}$ への依存性}

(General character of the dependence of $\rho$ on $E$ )

（4）式によつて定義される放電プラズマの比抵抗 $\rho$ の 瞬間值が放電管の構造や電源回路のパラメーターにどの ように依存するかという詳細な研究がなされた. Fig. 5 はこれらの研究で得られた放電の電圧一電流特性の例を を示军。

$C$ と $U_{0}$ の值がそれぞれ異なるおのおのの曲線は正の 勾配の部分 (準定常放電に属する) で皆一本の共通線に 合併している. このことはプラズマの前の状態に無関係 な単一の関数 $\rho=f(E)$ が存在することを立証している.

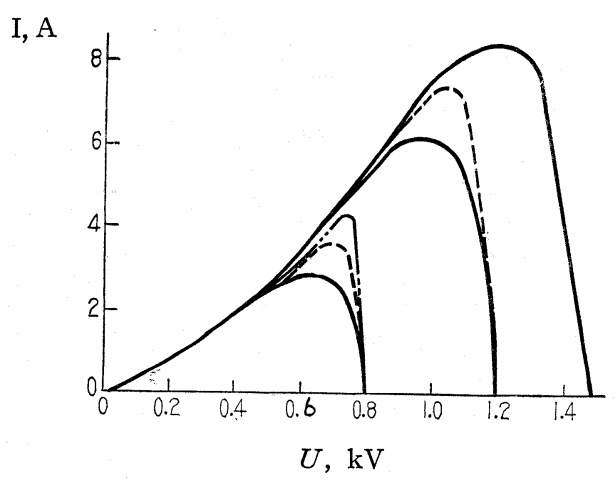

Fig. 1-5. Samples of volt-ampere characteristic. Xenon, $p=100 \mathrm{mmHg}, l=7 \mathrm{~cm}, t=0.17 \mathrm{~mm}$; $-C=0.1 \mu \mathrm{F}, \quad \cdots \cdots 0.25 \mu \mathrm{F}$, $--0.5 \mu \mathrm{F} ; U_{0}=0.8,1.2$, and $1.5 \mathrm{kV}$.

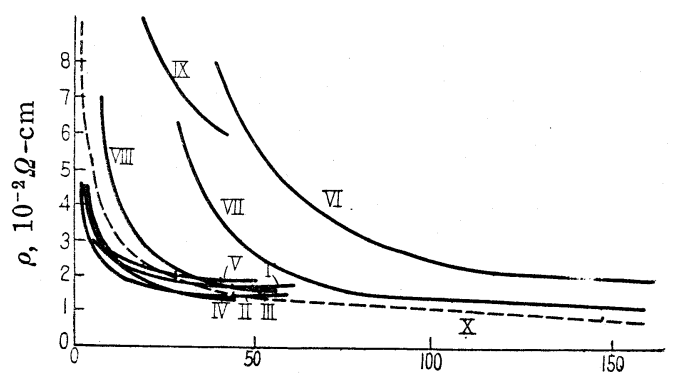

$E, \mathrm{~V} / \mathrm{cm}$

Fig. 1-6. Curve showing the dependence of $\rho$ on $E$ for tubes with different internal dischargetube diameters and different filling gases.

\begin{tabular}{|c|c|c|c|c|c|c|}
\hline $\begin{array}{l}\text { Number } \\
\text { of curve }\end{array}$ & I & II & III & IV & $\mathrm{V}$ & VI \\
\hline$l, \mathrm{~cm}$ & 50 & 50 & 29 & 36 & 36 & 7 \\
\hline$r, \mathrm{~mm}$ & 1 & 2.3 & 3.3 & 2 & 3.8 & 0.25 \\
\hline Gas & $\mathrm{Kr}$ & $\mathrm{Kr}$ & $\mathrm{Kr}$ & $\mathrm{Kr}$ & $\mathrm{Kr}$ & $\mathrm{Xe}$ \\
\hline$p, \mathrm{mmHg}$ & 100 & 100 & 100 & 100 & 100 & 600 \\
\hline$R_{b}, \Omega$ & 0 & 0 & 0 & 0 & 0 & 0 \\
\hline $\begin{array}{l}\text { Number } \\
\text { of curve }\end{array}$ & VII & VIII & \multicolumn{2}{|c|}{ IX } & \multicolumn{2}{|c|}{$\mathrm{X}$} \\
\hline$l, \mathrm{~cm}$ & 7 & 100 & \multicolumn{2}{|c|}{100} & \multirow{3}{*}{\multicolumn{2}{|c|}{$\begin{array}{l}\text { Empirical } \\
\text { function }\end{array}$}} \\
\hline$r, \mathrm{~mm}$ & 0.25 & 7 & \multicolumn{2}{|c|}{7} & & \\
\hline Gas & $\mathrm{Xe}$ & $\mathrm{Xe}$ & \multicolumn{2}{|c|}{$\mathrm{Xe}$} & & \\
\hline$p, \mathrm{mmHg}$ & 100 & 120 & \multicolumn{2}{|c|}{120} & \multicolumn{2}{|c|}{$Q=0.1$} \\
\hline$R_{b}, \Omega$ & 0 & 0 & \multicolumn{2}{|c|}{$0.67-48$} & \multicolumn{2}{|c|}{$Q=\overline{\sqrt{ }} \bar{E}$} \\
\hline
\end{tabular}

この比 $U / I$ がほぼ一定 (定抵抗) の部分は放電の主要 部で，この間にコンデンサからのエネルギーの 80〜90 パーセントが管内に放出される. 回路に $R_{b}$ が直列に入 つていると, 準定常放電の初期の夕 $\rho$ の值はこの関数か 
らはずれる。乙れはある時間内（ $R_{b}$ を増加するとこの 時間は長くなる) 放電が管の断面を完全に満さないから で，この場合には (4) 式は適用できない。

Fig. 6 以電圧一電流特性の共通線の部分から計算によ つて求めた $\rho$ と $E$ の関係を示す. curve I V V VIII は 普通の比較的太いチューブラフラッシュランプ, curve VI と VII はキャピラリ放電管である. curve IX は回 路に $R_{b}$ を入れた場合で $\rho$ 以高目に出るが， $R_{b}$ を減ら すか $U_{0}$ を高くすれば curve VIII に近づく。

Curve I〜V から同じガスを充填した放電管では, 長 さや内径が異なつていても $\rho$ と $E$ の瞬間值の間に実用 上単一の関数関係があることがわかる。(ただし径が 2 8 mm の範囲にあるものでしかも余り短くないもの) 同一寸法の放電管では，管内のガスの種類や圧力を変え ても $\rho$ は余り変らないことが実験によつて確かめられて いる.たとえばクリプトンをクセノンで置換しても $\rho$ は たつた15パーセントしが増加しないし，アルゴンだと約 10パーセントだけ減少する. $100 \mathrm{mmHg}$ から $25 \mathrm{mmHg}$ へ減压しても 10 20 パーセント減少するだけである. 管径が小さい場合には，Eの小さい領域では $\rho$ 高くなる 夰，Eが $100 \mathrm{~V} / \mathrm{cm}$ 以上のところではもつと太いものと の差はなくなる。

放電管の端方向から撮影した放電路の高速写真で, 放 電路の膨脹とその後の壁からの圧縮波の反射による直径 の減衰的な脈動を調べた結果, 放電路の抵抗は電源キャ パシタの電圧が余り低下しない限りその断面積に反比例 することがわからた、すなわち放電が管の断面を完全に 満した時だけでなく満さない場合にもこの関係に成り立 つ.（ただしこの場合，管の内径でなく，放電路の直径 を用いる.)

このように任意の寸法と任意の管内ガスのどえなチュ 一ブラフラッシュランプでも安定状態にある準定常放電 の瞬間抵抗を計算するのに, 大低の場合許容誤差の範囲 でいることができるある沉用函数 $\rho=f(E)$ を導入する ことが有利であるという結論に達した. 非常に細いキャ ピラリランプで比較的 $E$ が低い場合 $(100 \mathrm{~V} / \mathrm{cm}$ 以下 $)$ と回路 $R_{b}$ にが入つていて急激な電圧低下の停止および 準定常放電の成立直後だけは, 抵抗值はこのような計算 值と多少異なるはずである. 電源キャパシタの容量が小 さいため, 放電路管の全断面を満す余裕がない場合には もちろんずつと大きいRが得られるはずである.

Fig. 6 と実験データから余り細くない放電管の実効 抵抗して, 放電初期の $E \sim 50 \mathrm{~V} / \mathrm{cm}$ に対してクレノン ラッシュランプでは $\rho=0.02 \Omega-\mathrm{cm}$ を, クリプトンラン プでは $\rho=0.017 \Omega-\mathrm{cm}$ を用いることができる. $E$ の広
範囲な変化に対する放電管の瞬間抵抗值をもつと正確に 計算するには, $\rho$ の常数值の代りに $E$ の増加と共に幾分 減少する值を採る必要がある. Fig. 6 の curve X 亿見 られるように適当な関数として, 次の実験式を選ぶこと ができる。

$$
\rho=\frac{0.1}{\sqrt{E}}
$$

チューブラフラッシュランプから決定したこの実験式 をもつとEの大きいところまで延長すると，短いスパ 一ク放電や電流によつて懪発した金属蒸気中の放電の飽 和電流密度に達した後のプラズマの $\rho$ に関する sec. 2.2 のデータと一致していると見なすことができる. Fig. 7 は $E$ の大きい範囲までこれらのデータを（5）式と共に プロットしたものである.

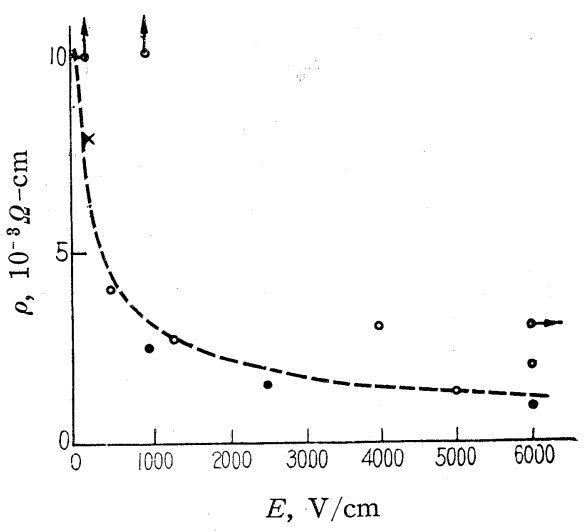

Fig. 1-7. Comparison of the empirical relation (5) with the experimental data for a short spark discharge and for a discharge in the vapor of a wire exploded by current. Circles-short spark discharge (black circles -in capillary, light circles-with unbounded channel), cross-discharge in wire vapor.

チューブラフラッシュランプはとの立ち上つている電 圧一電流特性から，キャパシタ流かりでなく他の電圧源， たとえば交流電力線からも給電できる。この場合ランプ は交流電圧の最大值の近くで点灯し, 電圧が零を通過す る時に消える. この放電はキャパシタ放電にくらべて持 続時間がずつと長い（50 C.P.S. の電力線では約 $1 / 200$ 秒）のと電圧変化が正弦的なのが特徵であるが, 電圧お よび電流オシログラムからランプの点灯後間もなくその 抵抗値は（4）式と（5）式から充分な確度で計算できる ことがわかる。

最近開発された超大電力クセノン連続グローランプ 
(定格数十 $\mathrm{kW}$ ) では, 電源電圧が零值を通過する間に 管内ガスはイオンから中性になる機会がないので, 電圧 の極性が反転した時直ちに逆方向の電流が流れる.この ようなランプでは放電路は管の断面の一部しか満さない ため，抵抗を計算する場合 (4) 式 $\rho$ の代りに $\rho / \theta^{2}$ を 代入する必要がある. $\theta$ 注放電路の直径と管の内径との 比である. $(\theta \cong 0.5)$ Fig. 6 涀られるように $E<10$ $\mathrm{V} / \mathrm{cm}$ のところで過大な $\rho$ の值を与える (5) 式の代りに 次式を用いる.

$$
\stackrel{\rho}{\theta^{2}}=0.065 p_{0}^{\frac{1}{2}} r^{-\frac{1}{2}} E^{-\frac{3}{2}}
$$

この式は $\rho, \theta, E$ の実効值と電流祘よび電圧オシロ グラムや放電路の太さの流し写真から計算された瞬間值 の両方に適合するし，また $R_{b}$ の大つたフラッシュラン プのコンデンサ放電 (Fig. 6 の plate IX) 初期に高く 出た $\rho$ の值とも一致する.

チャネル中の気体が高度に電離している放電の電気的 特性を理論的飞近似計算する試みは多数発表されている が、乙机らの多くは, あるパラメー夕は実験資料に基づ いて決定されると仮定している．たとえばコラムの $\rho$ を 計算するのに管壁でのエネルギー損失を壁上のイオン電 流の実駼值から計算し, 放射エネルギーも実験による見 積から無視できるほど小さいと仮定している. 束縛され ないチャネルの場合はその直径を実験データから求め, 放射パワー注同寸法の絶体黑体に等しいと置いている. また放電電力に実験值安用い, 温度は放射特性から算出 てているのもある. 一方放電のすべての物理的なパラメ 一タの組み合わせた理論計算も試みられているが, 複雄 な計算の結果を個及の実験結果と比較することができる だけで，パラメータ間相互を関連させた完全な像は与光 ない. 熱力学的平衡, イオンによる電子の散乱, 放電管 の全断面にわたるコラムの均一性, 壁面での再結合と水 素的再結合放射によるエネルギー損失を仮定したもつと 近似的な計算では，実験で観測されたような放電特性の パメータへの基本的な依存性を導き出すことができた.

Fig. 8 と Fig. 9 に $E$ と による $\rho, T$, ク（光源として の放電の効率）の変化が図示されているが，Fig. 8 の 細線は上に述べた仮定に基づいて計算した $\rho$, 点線は 同じ式を用いているが，係数を実験值で修正したもので 亦る。

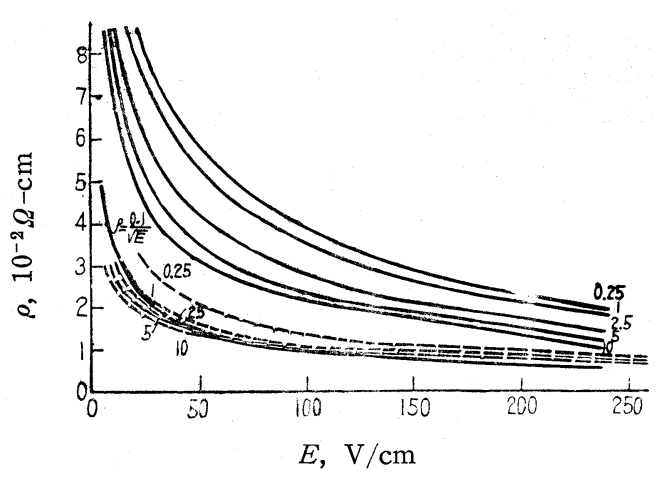

Fig. 1-8. Plots of $\rho=f(E)$, calculated for krypton lamps with internal tube radii $0.25,1,2.5$, 5 , and $10 \mathrm{~mm}$. The solid lines correspond to approximate calculations, dashed linesto formulas calculated with numerical coefficients corrected by means of a separate set of experimental quantities, thick lineplot of the empirical relation (5).

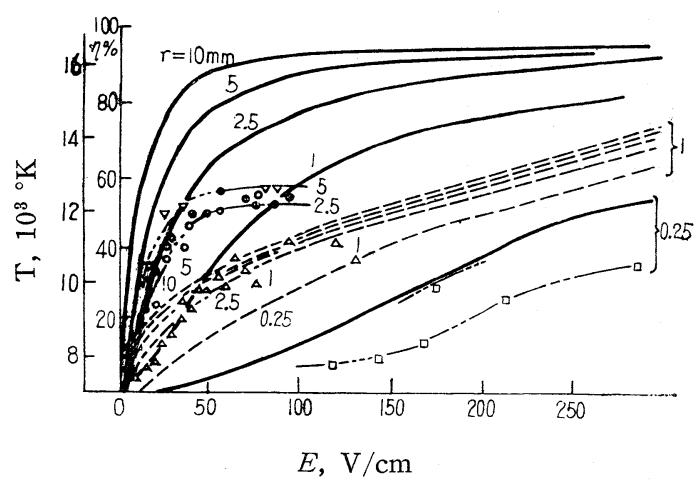

Fig. 1-9. Calculated plots of the dependence of the plasma temperature $T$ on $E$ (dashed) and on the discharge efficiency $\eta$ (solid lines), obtained for corrected coefficients. Krypton, $p=100 \mathrm{mmHg}, l=50 \mathrm{~cm}, r=0.25$, $1,2.5$, and $5 \mathrm{~mm}$. Dash-dot line-averaged experimental plots of $\eta$, plotted on the basis of the following points: $\bigcirc-r=0.25 \mathrm{~mm}$, $\triangle-1 \mathrm{~mm}, \quad \bigcirc-2.5 \mathrm{~mm}, \quad \nabla-5 \mathrm{~mm}$ (filled experimental points were obtained for $C>$ $600 \mu \mathrm{F}$, half-filled points $-125 \mu \mathrm{F}$, unfilled$80 \mu \mathrm{F}$, with vertical bar $-48 \mu \mathrm{F}$, horizontal bar $-14 \mu \mathrm{F}$, cross $-0.25 \mu \mathrm{F}$. 